\title{
SYNTHESES AND CHARACTERIZATION OF COPPER (II) AND PALLADIUM (II) COMPLEXES WITH 2-(ARYLMETHYLENEACETYL)BENZIMIDAZOLE
}

\author{
M. Abdelbaset \\ Chemistry Department, Faculty of Science, Al Azhar University Assiut branch, Assiut, Egypt. \\ Author to whom correspondence should be addressed (Baset1002002@yahoo.co.uk)
}

\begin{abstract}
Metal complexes formed through the reaction of 2-(Arylmethyleneacetyl) benzimidazole (L1-L4) with copper (II) and palladium (II) ions were prepared and characterized by elemental analysis, conductance measurements, infrared spectra, electronic absorption spectra, X-ray diffraction and thermal analyses. The 2-(Arylmethyleneacetyl)benzimidazole (L1-L4) coordinate as neutral bidentate ligands. The final product in all the cases of TG thermogram of the complexes was found to be metal oxides. Complexes of copper (II) and palladium (II) with 2-(Arylmethyleneacetyl)benzimidazole in solution were studied by spectrophotometric methods and the formation constants and stioichiometries of the complexes were calculated to be 1:2 (M:L) as calculated by continuous variations and the mole ratio methods. The stability sequence is in agreement with the Irving-Williams rule.
\end{abstract}

Keywords: Copper (II), Palladium (II), Complexes, X-ray diffraction, Thermal analyses, UV-Vis spectroscopy.

\section{INTRODUCTION}

Benzimidazole and its derivatives are interesting heterocycles because of their presence in many medicaments. It has been found that they possess antibacterial, antifungal, antioxidant, antihistaminic, cytostatic, local analgesic, hypotensive antihelmintic, anticancer, antihypertensive, antineoplastic, antiprotozoal, anti-hepatitis B virus and anti-inflammatory activity ${ }^{(1-6)}$. It was confirmed to have a moderate in vitro anti-HIV activity ${ }^{(7,8)}$. Also Benzimidazole as its 5,6-dimethyl derivative is present in vitamin B12 and related biomolecules and benzimidazole derivatives have found wide uses as antihelmintic agents for both human and veterinary purposes ${ }^{(9)}$. Benzimidazoles are also used extensively in industrial processes as corrosion inhibitors for metal and alloy surfaces particularly of copper ${ }^{(10)}$ and ion exchangers ${ }^{(11)}$.

Complex compounds of transition metal ions with benzimidazole and substituted compounds of these ligands have been studied extensively ${ }^{12-}$ 16). In the recent time, possible therapeutic properties of the metal complexes have been examined. It was found that the complexes of transition metals with benzimidazole derivatives have a higher antimicrobial activity than the corresponding ligands ${ }^{(17-21)}$.

Synthesis, characterization and antimicrobial activities of transition metal complexes of 1,3bis(benzimidazolyl/N-methylbenzimidazolyl)be nzene have been reported ${ }^{(18-23)}$.

The aim of the present article is to prepare and characterize Copper (II) and palladium (II) complexes with 2-(Arylmethyleneacetyl)benzim idazole derivatives and their characterization by Elemental analysis, conductance measurements, TGA, UV-Visible, IR, thermal analyse as and $\mathrm{X}$-ray diffraction were used to investigate the titled complexes.

\section{Experimental}

All the chemicals were of analytical reagent grade; the ligands 2-(Arylmethyleneacetyl)benzi midazole $\left(\mathrm{L}_{1}-\mathrm{L}_{4}\right)$ were prepared by procedure of Zeinab ${ }^{(24)}$. All solutions were prepared with doubly distilled water. The solutions were diluted as necessary to prepare standard working solution.<smiles>[R]c1ccc(/C=C/C=O)cc1</smiles>

$$
\begin{aligned}
& \text { Where } \mathrm{R}=\mathrm{H}\left(\mathrm{L}_{1}\right), \\
& \mathrm{p}-\mathrm{Cl}\left(\mathrm{L}_{2}\right), \\
& \mathrm{p}-\mathrm{NO}_{2}\left(\mathrm{~L}_{3}\right), \quad \mathrm{p}-\mathrm{N}\left(\mathrm{CH}_{3}\right)_{2}\left(\mathrm{~L}_{4}\right)
\end{aligned}
$$

Fig. 1. Structure of the Ligand 2-(Arylmethyl eneacetyl)benzimidazole $\left(\mathrm{L}_{1}-\mathrm{L}_{4}\right)$. 


\section{Preparation of the solid complexes}

A solution of $\mathrm{Cu}(\mathrm{II})$ or $\mathrm{Pd}(\mathrm{II})$ chloride $(0.01$ mole dissolved in $25 \mathrm{ml}$ ethanol) was added to a hot ethanolic solution of the ligands $\left(\mathrm{L}_{1}-\mathrm{L}_{4}\right)(0.02$ mole in $25 \mathrm{ml}$ ethanol) in stoichiometric ratio 1:2 (metal ion : ligand). The mixture was refluxed for about 4 hours, the solid complexes were filtered on a water pump and washed several times with ethanol and dried in vacuum over $\mathrm{P}_{4} \mathrm{O}_{10}$.

\section{Physical measurement and analyses}

Electronic spectra of solutions of the complexes in DMF were recorded on a Perkin - Elmer Lambada 3B Spectrophotometer. The IR spectra were recorded on a Shimadzu IR 470 (4000-400) spectrophotometer using $\mathrm{KBr}$ discs. TGA measurements were carried out with a shimadzu thermal analyses 50, at heating rate of $20^{\circ} \mathrm{C} / \mathrm{min}$.

Conductivity was measured in solutions of the complexes in DMF $\left(10^{-3} \mathrm{M}\right)$ using Hana conductivity bridge (Model) $\mathrm{HI} 8819$ at $25^{\circ} \mathrm{C}$.

Microanalyses for $\mathrm{C}, \mathrm{H}, \mathrm{N}$ were carried out at the Microanalytical center, Assiut University.

X-ray was carried out with Philips X-ray PW 1710 diffractometer using Ni-filtered $\mathrm{CuK} \alpha$ radiation, Assiut University.

\section{RESULT AND DISCUSSION:}

The complex formation reaction of the ligands $\left(\mathrm{L}_{1}-\mathrm{L}_{4}\right)$ with $\mathrm{Cu}(\mathrm{II})$ and $\mathrm{Pd}(\mathrm{II})$ halides can be represented by the following equations:

$$
\mathrm{MX}_{2}+2 \mathrm{~L} \rightarrow\left[\mathrm{ML}_{2} \mathrm{X}_{2}\right]
$$

Where $\mathrm{M}=\mathrm{Cu}$ (II) and $\mathrm{Pd}$ (II), $\mathrm{X}=\mathrm{Cl}$

They are soluble in DMF, DMSO, Acetone and slightly soluble in Ethanol, methanol.

The complexes were characterized by chemical analyses, IR and visible spectra, thermal analyses and conductivity measurements.

Molar conductance values for the solid complexes $\left(1 \times 10^{-3} \mathrm{M}\right.$ DMF solution) indicates that the complexes are non-electrolytes ${ }^{(25)}$.

\section{Infrared spectra}

The infrared spectra of the free ligand are recorded in the $4000-400 \mathrm{~cm}^{-1}$ re- gion and compared with the spectra of the $\mathrm{Cu}$ (II) and $\mathrm{Pd}(\mathrm{II})$ complexes. The characteristic of the ligand and complexes bands are listed in Table (1).

The IR spectrum of the free ligand display a stretching band at $3250-3450 \mathrm{~cm}^{-1}$ attributed to $v \mathrm{NH}^{(24)}$. Also the free ligands spectrum exhibits a strong band at $1650-1662 \mathrm{~cm}^{-1}$ is due to $\mathrm{C}=\mathrm{O}$ stretching frequency The band corresponding to $v(\mathrm{C}=\mathrm{N})$ vibration group is shifted to lower or higher values in the spectra of the complexes indicating that the nitrogen atom shared in coordination with metal ion in these complexes. Also other absorption band in the IR spectra of the free ligands at $1580-1595 \mathrm{~cm}^{-1}$ attributed to the $\mathrm{C}=\mathrm{N}$ group and The $v(\mathrm{C}=\mathrm{O})$ absorption is also shifted to a lower or higher frequency indicating that the ligand is coordinated with the metal ion through the oxygen of the carbonyl group (26).

The IR spectrum also exhibits stretching band of the free ligand at $1485-1540 \mathrm{~cm}^{-1}$ attributed to the $\mathrm{C}=\mathrm{C}$ of skeletal benzonoid moieties of these ligand, but these bann the complexes are slightly shifted compared to the free ligands.

So the conclusive evidence of the coordination of the 2-(Arylmethyleneacetyl)benzimidazo le $\left(\mathrm{L}_{1}-\mathrm{L}_{4}\right)$ with the metal ions was shown by the appearance new bands at $482-505 \mathrm{~cm}^{-1}$ and 525 $585 \mathrm{~cm}^{-1}$ assigned to the metal nitrogen $(\mathrm{M}-\mathrm{N})$ (27-29) and metal-oxygen $(\mathrm{M}-\mathrm{O})^{(30)}$ vibrations, respectively. These bands were absent in the spectrum of the ligand itself, thus confirming participation of the $\mathrm{O}$ and $\mathrm{N}$ atoms in the coordination.

The x-ray powder diffraction patterns for the complexes of $\mathrm{Cu}(\mathrm{II})$ and $\mathrm{Pd}(\mathrm{II})$ with 2 -

(Arylacetyl)benzimidazole are depicted in Figs. 2-4. They indicate that the Pd(II) complexes with $\mathrm{L}_{2}$ and $\mathrm{L}_{3}$ are crystalline (Fig. 2), also the $\mathrm{Cu}$ (II) complex with $\mathrm{L}_{1}, \mathrm{~L}_{2}$ and $\mathrm{L}_{3}$ are semicrystalline(Fig. 3), while the $\mathrm{Cu}$ (II) complex with $\mathrm{L}_{4}$ is amorphous (Fig. 4). This indicates that the polymeric structure of $\mathrm{Cu}$ (II) complexes with $\mathrm{L}_{1}, \mathrm{~L}_{2}, \mathrm{~L}_{3}$ and $\mathrm{L}_{4}$ are more convenient, while the $\mathrm{Pd}$ (II) complexes with $\mathrm{L}_{2}$ and $\mathrm{L}_{3}$ have a monomeric structure. 
Syntheses and Characterization of Copper (II) and Palladium (II) Complexes with 2

Table 1. Characteristic infrared bands and $\lambda$ max electronic absorption bands of the 2-(Arylmethylenea cetyl)benzimidazole $\left(\mathrm{L}_{1}-\mathrm{L}_{4}\right)$ and its $\mathrm{Cu}$ (II) and Pd (II) complexes.

\begin{tabular}{|c|c|c|c|c|c|c|c|}
\hline Compound & $v N H$ & $v \mathrm{C}=\mathrm{O}$ & $v \mathrm{C}=\mathrm{N}$ & $v \mathrm{C}=\mathrm{C}$ & $v \mathrm{M}-\mathrm{O}$ & $v \mathrm{M}-\mathrm{N}$ & $\lambda_{\max } \mathrm{nm}$ \\
\hline $\mathrm{L}_{1}$ & 3250 & 1650 & 1580 & 1510 & - & - & 330 \\
\hline$\left[\mathrm{Cu}\left(\mathrm{L}_{1}\right)_{2} \mathrm{Cl}_{2}\right]$ & 3450 & 1655 & 1695 & 1517 & 585 & 490 & 430 \\
\hline$\left[\mathrm{Pd}\left(\mathrm{L}_{1}\right)_{2} \mathrm{Cl}_{2}\right] \mathrm{H}_{2} \mathrm{O}$ & 3150 & 1670 & 1600 & 1400 & 575 & 495 & 460 \\
\hline $\mathrm{L}_{2}$ & 3420 & 1662 & 1595 & 1485 & - & - & 332 \\
\hline$\left[\mathrm{Cu}\left(\mathrm{L}_{2}\right)_{2} \mathrm{Cl}_{2}\right]$ & 3340 & 1650 & 1585 & 1485 & 575 & 495 & 413 \\
\hline$\left[\mathrm{Pd}\left(\mathrm{L}_{2}\right)_{2} \mathrm{Cl}_{2}\right] \mathrm{H}_{2} \mathrm{O}$ & 3100 & 1678 & 1590 & 1483 & 580 & 482 & 455 \\
\hline $\mathrm{L}_{3}$ & 3300 & 1658 & 1585 & 1508 & - & - & 340 \\
\hline$\left[\mathrm{Cu}\left(\mathrm{L}_{3}\right)_{2} \mathrm{Cl}_{2}\right] \mathrm{H}_{2} \mathrm{O}$ & 3450 & 1655 & 1590 & 1510 & 525 & 505 & 423 \\
\hline$\left[\mathrm{Pd}\left(\mathrm{L}_{3}\right)_{2} \mathrm{Cl}_{2}\right] \mathrm{H}_{2} \mathrm{O}$ & 3150 & 1682 & 1587 & 1510 & 540 & 485 & 64 \\
\hline $\mathrm{L}_{4}$ & 3450 & 1658 & 1595 & 1540 & - & - & 436 \\
\hline$\left[\mathrm{Cu}\left(\mathrm{L}_{4}\right)_{2} \mathrm{Cl}_{2}\right] \mathrm{H}_{2} \mathrm{O}$ & 3350 & 1640 & 1585 & 1525 & 540 & 485 & 435 \\
\hline$\left[\mathrm{Pd}\left(\mathrm{L}_{4}\right)_{2} \mathrm{Cl}_{2}\right] \mathrm{H}_{2} \mathrm{O}$ & 3150 & 1620 & 1590 & 1520 & 558 & 497 & 480 \\
\hline
\end{tabular}

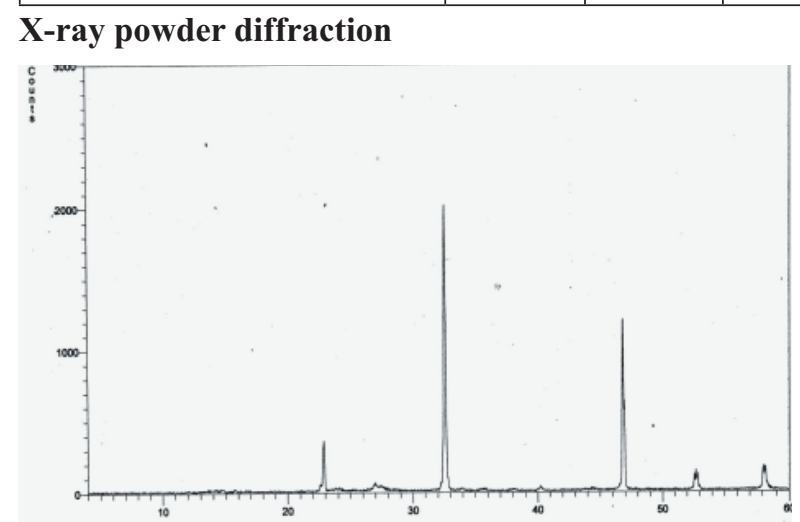

Fig. 2. X-ray powder diffraction pattern of $[\mathrm{Pd}$ $\left.\left(\mathrm{L}_{3}\right)_{2} \mathrm{Cl}_{2}\right] \mathrm{H}_{2} \mathrm{O}$ complex.

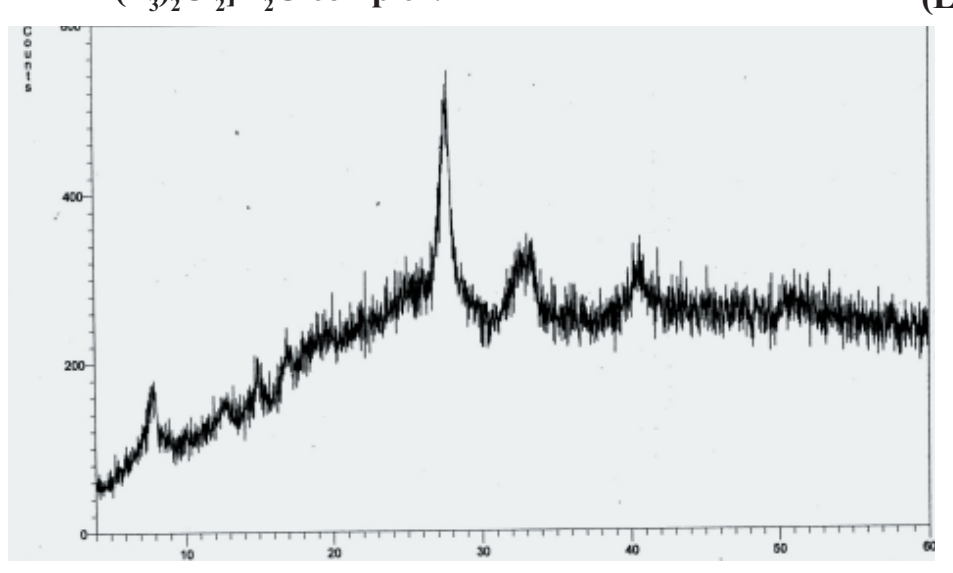

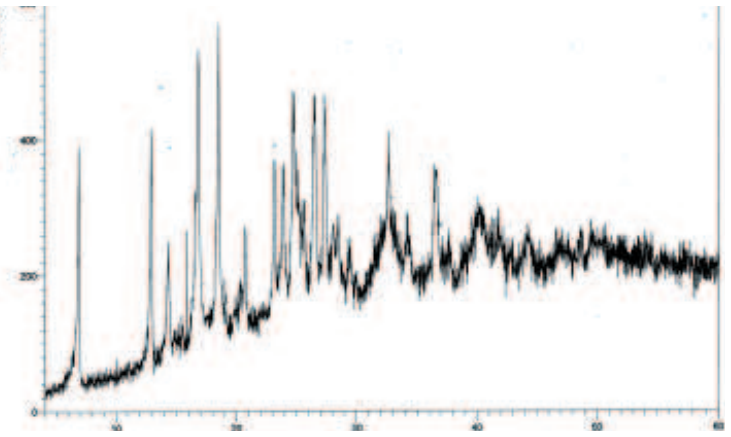

Fig. 3. X-ray powder diffraction pattern of $[\mathrm{Cu}$ $\left.\left(\mathrm{L}_{3}\right)_{2} \mathrm{Cl}_{2}\right] \mathrm{H}_{2} \mathrm{O}$ complex.

Fig. 3. X-ray powder diffraction pattern of $\left[\mathrm{Cu}\left(\mathrm{L}_{4}\right) 2 \mathrm{Cl}_{2}\right] \mathrm{H}_{2} \mathrm{O}$ complex.

\section{Microanalysis:}

The elemental analysis (C.H.N) of the isolated complexes of $\mathrm{Cu}(\mathrm{II})$ and $\mathrm{Pd}(\mathrm{II})$ with 2(Arylacetyl)benzimidazole $\left(\mathrm{L}_{1}-\mathrm{L}_{4}\right)$ were found to be in agreement with calculated values which support the proposed formula of the complexes, Table (2),

These were ascertained by the continuous 
Table 2. Elemental analysis result of the $\mathrm{Cu}$ (II) and $\mathrm{Pd}(\mathrm{II})$ complexes with 2-(Arylme- thyleneacetyl)benzi midazole derivatives.

\begin{tabular}{|c|c|c|c|c|}
\hline \multirow{2}{*}{ Complex } & \multirow{2}{*}{ Formula } & \multicolumn{3}{|c|}{ Found (Calc.)\% } \\
\hline & & $\mathrm{C} \%$ & $\mathrm{H} \%$ & N\% \\
\hline$\left[\mathrm{Cu}\left(\mathrm{L}_{1}\right)_{2} \mathrm{Cl}_{2}\right]$ & $\mathrm{C}_{32} \mathrm{H}_{24} \mathrm{~N}_{4} \mathrm{O}_{2} \mathrm{Cl}_{2} \mathrm{Cu}$ & $\begin{array}{l}60.50 \\
(60.9)\end{array}$ & $\begin{array}{c}3.46 \\
(3.83)\end{array}$ & $\begin{array}{c}8.66 \\
(8.88)\end{array}$ \\
\hline$\left[\mathrm{Pd}\left(\mathrm{L}_{1}\right)_{2} \mathrm{Cl}_{2}\right] \mathrm{H}_{2} \mathrm{O}$ & $\mathrm{C}_{32} \mathrm{H}_{26} \mathrm{~N}_{4} \mathrm{O}_{3} \mathrm{Cl}_{2} \mathrm{Pd}$ & $\begin{array}{c}55.20 \\
(55.55)\end{array}$ & $\begin{array}{c}4.10 \\
(3.78)\end{array}$ & $\begin{array}{c}8.40 \\
(8.09)\end{array}$ \\
\hline$\left[\mathrm{Cu}\left(\mathrm{L}_{2}\right)_{2} \mathrm{Cl}_{2}\right]$ & $\mathrm{C}_{32} \mathrm{H}_{22} \mathrm{~N}_{4} \mathrm{O}_{2} \mathrm{C}_{14} \mathrm{Cu}$ & $\begin{array}{c}54.50 \\
(54.91)\end{array}$ & $\begin{array}{c}2.53 \\
(3.16)\end{array}$ & $\begin{array}{c}7.73 \\
(8.01)\end{array}$ \\
\hline$\left[\mathrm{Pd}\left(\mathrm{L}_{2}\right)_{2} \mathrm{C}_{12}\right] \mathrm{H}_{2} \mathrm{O}$ & $\mathrm{C}_{32} \mathrm{H}_{24} \mathrm{~N}_{4} \mathrm{O}_{3} \mathrm{Cl}_{4} \mathrm{Pd}$ & $\begin{array}{c}50.80 \\
(50.51) \\
\end{array}$ & $\begin{array}{c}3.52 \\
(3.17) \\
\end{array}$ & $\begin{array}{c}6.95 \\
(7.36) \\
\end{array}$ \\
\hline$\left[\mathrm{Cu}\left(\mathrm{L}_{3}\right)_{2} \mathrm{C}_{12}\right] \mathrm{H}_{2} \mathrm{O}$ & $\mathrm{C}_{32} \mathrm{H}_{24} \mathrm{~N}_{6} \mathrm{O}_{7} \mathrm{C}_{12} \mathrm{Cu}$ & $\begin{array}{c}51.82 \\
(52.00) \\
\end{array}$ & $\begin{array}{c}2.96 \\
(3.27) \\
\end{array}$ & $\begin{array}{c}11.58 \\
(11.37)\end{array}$ \\
\hline$\left[\mathrm{Pd}\left(\mathrm{L}_{3}\right)_{2} \mathrm{C}_{12}\right] \mathrm{H}_{2} \mathrm{O}$ & $\mathrm{C}_{32} \mathrm{H}_{24} \mathrm{~N}_{6} \mathrm{O}_{7} \mathrm{C}_{12} \mathrm{Pd}$ & $\begin{array}{c}49.58 \\
(49.15)\end{array}$ & $\begin{array}{c}3.31 \\
3.09))\end{array}$ & $\begin{array}{c}11.08 \\
(10.74)\end{array}$ \\
\hline$\left[\mathrm{Cu}\left(\mathrm{L}_{4}\right)_{2} \mathrm{C}_{12}\right] \mathrm{H}_{2} \mathrm{O}$ & $\mathrm{C}_{36} \mathrm{H}_{36} \mathrm{~N}_{6} \mathrm{O}_{3} \mathrm{Cl}_{2} \mathrm{Cu}$ & $\begin{array}{c}59.10 \\
(58.81)\end{array}$ & $\begin{array}{c}4.70 \\
(4.93)\end{array}$ & $\begin{array}{c}10.95 \\
(11.43)\end{array}$ \\
\hline$\left[\mathrm{Pd}\left(\mathrm{L}_{4}\right)_{2} \mathrm{C}_{12}\right] \mathrm{H}_{2} \mathrm{O}$ & $\mathrm{C}_{36} \mathrm{H}_{36} \mathrm{~N}_{6} \mathrm{O}_{3} \mathrm{Cl}_{2} \mathrm{Pd}$ & $\begin{array}{c}55.30 \\
(55.57)\end{array}$ & $\begin{array}{c}4.25 \\
(4.66)\end{array}$ & $\begin{array}{c}10.90 \\
(10.80)\end{array}$ \\
\hline
\end{tabular}

variation and molar ratio methods. The results reveal that the stoichiometry is $1: 2$ (metal: ligand) ratio for each complex.

\section{Thermal Analyses}

Thermal analyses of the $\left[\mathrm{Pd}\left(\mathrm{L}_{2}\right)_{2} \mathrm{Cl}_{2}\right] \mathrm{H}_{2} \mathrm{O}$ complex (Fig. 5), was studied using the $\mathrm{TG}$ technique. The thermo gravimetric studies of the complex were carried out in the temperature range $30-800{ }^{\circ} \mathrm{C}$ with a sample heating rate $20^{\circ} \mathrm{C} / \mathrm{min}$ in Nitrogen. The complex become anhydrous at $100{ }^{\circ} \mathrm{C}$ and the loss of weight was equal to $2.3 \%$ corresponding to the loss one molecule of water. DTA curve show an endothermic band due to the elimination of water, thus indicating that the water molecule are present in the outer sphere of the complex. The TG curve of $\left[\mathrm{Pd}\left(\mathrm{L}_{2}\right)_{2} \mathrm{Cl}_{2}\right] \mathrm{H}_{2} \mathrm{O}$ complex also indicate a loss of weight at $150-400{ }^{\circ} \mathrm{C}$ equal $23.6 \%$ due to the loss of two PhCH. The final step of the decomposition occurs within the temperature range 400-750 0C corresponding to the decomposition of the complexe with the formation of the metal oxide $(\mathrm{PdO})$ as a final product.

The thermal decompositions of $[\mathrm{Cu}$ $\left.\left(\mathrm{L}_{3}\right)_{2} \mathrm{Cl}_{2}\right] \mathrm{H}_{2} \mathrm{O}$ complex (Fig. 6) displays three steps, the first step in the range $50-300{ }^{\circ} \mathrm{C}$ corresponding to the loss of one water molecule and two $\mathrm{HCl}$ molecules (12.5\%). The second decomposition step at $300-450^{\circ} \mathrm{C}$ can be attributed to the removal of two molecules of $\mathrm{NO}_{2}$ $(12.4 \%)^{(31)}$. The third decomposition step at 450 $-750^{\circ} \mathrm{C}(89 \%)$ attributed to complete decomposition of parent molecule leaving copper oxide $(\mathrm{CuO})$ as stable end product.

The TGA characteristic of the $\left[\mathrm{Cu}\left(\mathrm{L}_{1}\right)_{2} \mathrm{Cl}_{2}\right]$ complex have two decomposition steps (Fig. 7). The first step at $200-350{ }^{\circ} \mathrm{C}(11.6 \%)$ corresponds to elimination of two $\mathrm{HCl}$ molecules ${ }^{(32)}$. The second weight-loss step between $350-750^{\circ} \mathrm{C}$ may be attributed to the loss of organic moiety of the complex molecule $(87.5 \%)$. The final de-

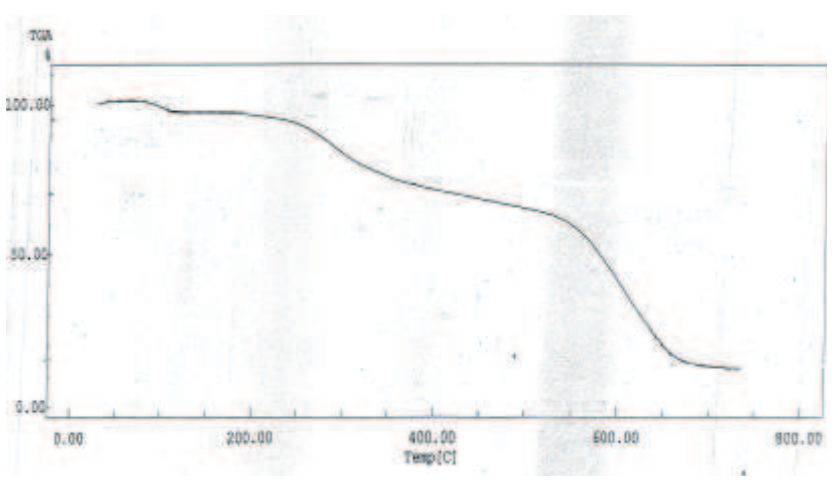

Fig. 5. TG diagram of $\left[\mathrm{Pd}\left(\mathrm{L}_{2}\right)_{2} \mathrm{Cl}_{2}\right] \mathrm{H}_{2} \mathrm{O}$ complex. 


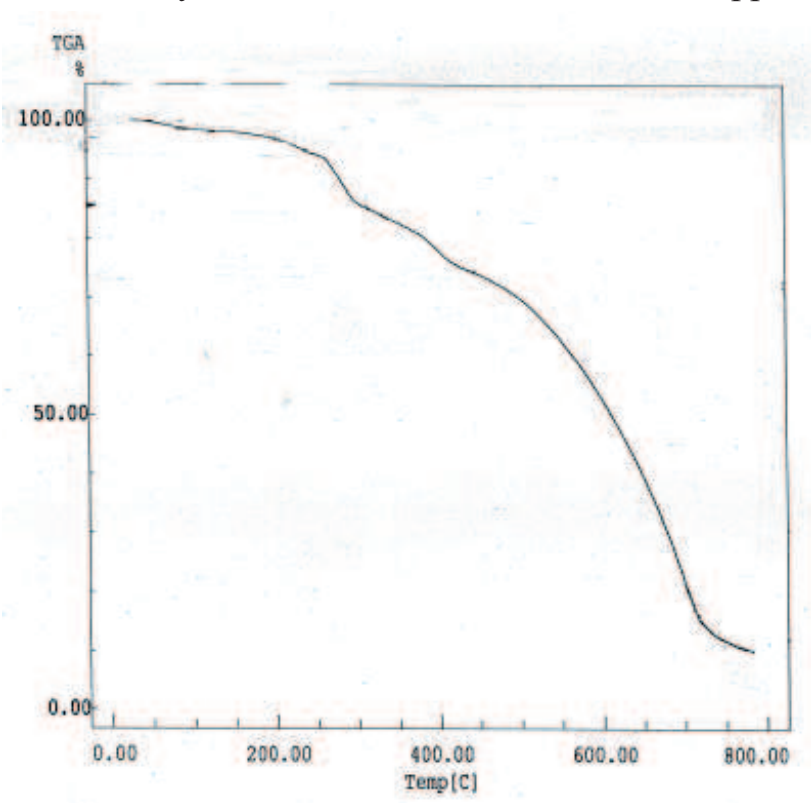

Fig. 6. TG diagram of $\left[\mathrm{Cu}\left(\mathrm{L}_{3}\right)_{2} \mathrm{Cl}_{2}\right] \mathrm{H}_{2} \mathrm{O}$ complex.

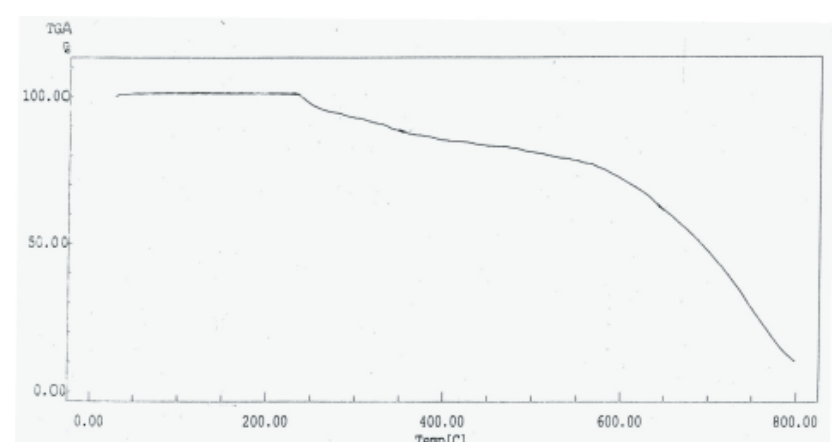

Fig. 7. TG diagram of $\left[\mathrm{Cu}\left(\mathrm{L}_{1}\right)_{2} \mathrm{Cl}_{2}\right]$ complex.

composition continuous up to $800{ }^{\circ} \mathrm{C}$ and on further increasing the temperature no weight loss is observed which may be attributed to formation of stable metal oxide $(\mathrm{CuO})$. .

\section{Electronic spectra}

The absorption spectra of the 2-(Arylmeth yleneacetyl)benzimidazole $\left(\mathrm{L}_{1}-\mathrm{L}_{4}\right)$ in ethanol exhibit a main absorption at $330 \mathrm{~nm}, 332 \mathrm{~nm}$, $340 \mathrm{~nm}$ and $436 \mathrm{~nm}$ for $\mathrm{L}_{1}-\mathrm{L}_{4}$ respectively. The maximum absorption of bands of the $\mathrm{Cu}(\mathrm{II})$ and Pd(II) complexes with 2-(Arylacetyl)benzimida zole $\left(\mathrm{L}_{1}-\mathrm{L}_{4}\right)$ are recorded in Table (1).

Comparison of electronic absorption spectra of free ligands $\left(\mathrm{L}_{1}-\mathrm{L}_{4}\right)$ with that of the chelated $\mathrm{Cu}(\mathrm{II})$ and $\mathrm{Pd}(\mathrm{II})$, reveals that the addition of metal ion to 2-(Arylacetyl)benzimidazole $\left(\mathrm{L}_{1}-\mathrm{L}_{4}\right)$ ligand solutions results in band shift to longer wavelength, which is an evidence for the formation of the coordination compounds.

Determination of the Stoichiometry and Formation Constants of the Complexes:

Complexes were studied in solution using ethanol as a solvents in order to determine the $[\mathrm{M}: \mathrm{L}]$ ratio in the complexes. The stoichiometry of the 2-(Arylmethyleneacetyl)benzimidazo le $\left(\mathrm{L}_{1}-\mathrm{L}_{4}\right)$ with $(\mathrm{Cu}(\mathrm{II})$ and $\mathrm{Pd}(\mathrm{II}))$ complexes
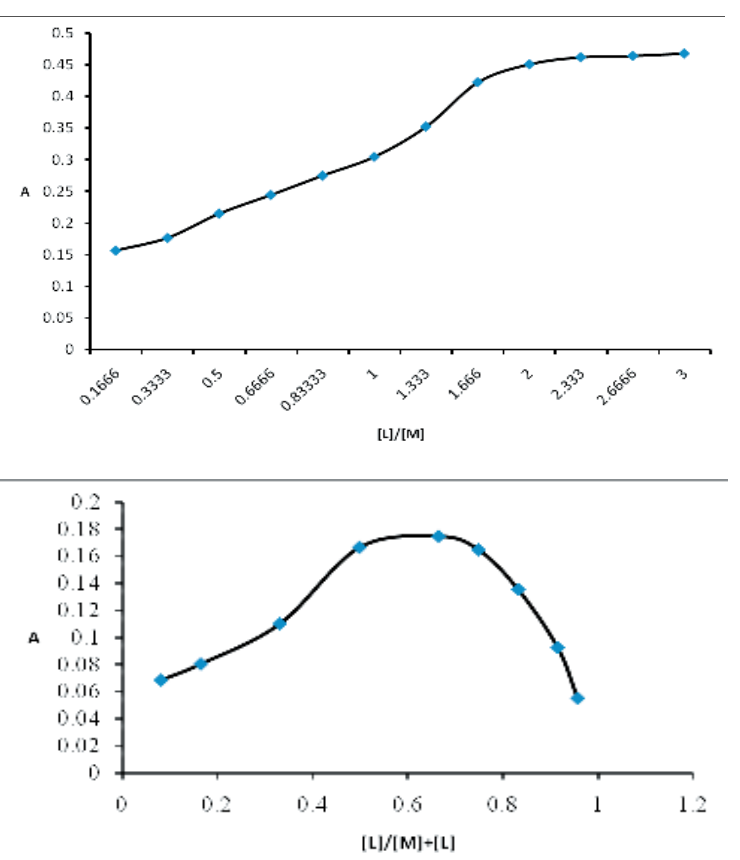

Fig.8. Molar ratio and continuous variation curve for Pd (II) $\mathrm{L}_{3}$ complex.

were verified to be 1:2 (metal : ligand) by applying the two spectrophotometric methods

i- Molar ratio method ${ }^{(33)}$ ii- Jobs continuous variation method ${ }^{(34)}$

as shown in Figure 8.

The formation constant $\left(\mathrm{K}_{\mathrm{f}}\right)$ of the complexes are determined by using data from the

continuous variation method (Job's plot) and molar ratio method.

The formation constant $\left(\mathrm{K}_{\mathrm{f}}\right)$ is determined by using the following relation ${ }^{(35,36)}$ :

$$
\mathrm{K}_{\mathrm{f}}=\frac{\mathrm{A} / \mathrm{Am}}{4 \mathrm{C}^{2}(1-\mathrm{A} / \mathrm{Am})^{3}}
$$

The results in Table (3) reveal the following features: 


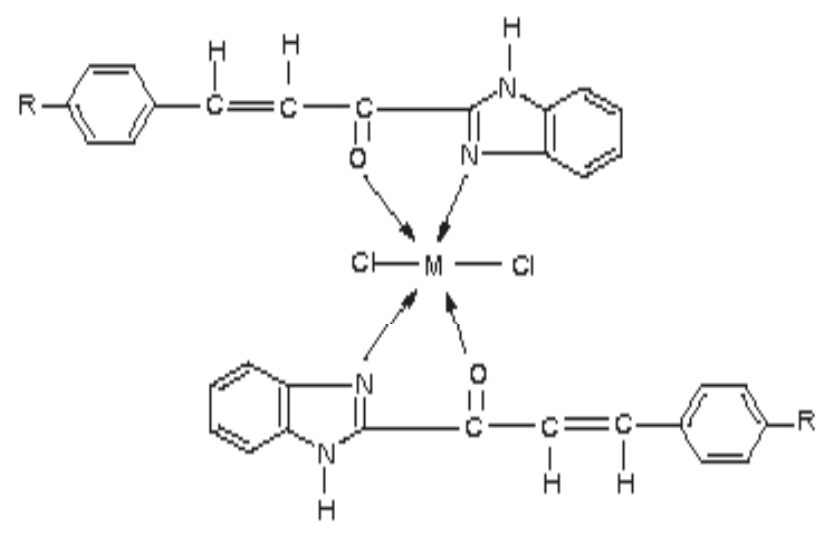

Where $\mathrm{M}=\mathrm{Cu}$ (II), $\mathrm{Pd}$ (II) and $\mathrm{R}=\mathrm{L}_{1}(\mathrm{H}), \mathrm{L}_{2}(\mathrm{p}$ $\mathrm{Cl}), \mathrm{L}_{3}\left(\mathrm{p}-\mathrm{NO}_{2}\right), \mathrm{L}_{4}\left(\mathrm{p}-\mathrm{N}\left(\mathrm{CH}_{3}\right)_{2}\right)$

Fig. 9, Proposed structure of the complexes.
In general, the stability of the complexes of the same ligand goes in order $\mathrm{Cu}$ (II) $>\mathrm{Pd}$ (II). This order agrees with the conclusions reached by Grinberg and Yatsimirki ${ }^{\left({ }^{37}\right)}$ and by Irving and Williams ${ }^{(38)}$.

Also The complexes stability of the same metals with the different ligands $\left(\mathrm{L}_{1}-\mathrm{L}_{4}\right)$ increase in the following order:

$\mathrm{L}_{4}\left(\mathrm{R}=\mathrm{p}-\mathrm{N}\left(\mathrm{CH}_{3}\right)_{2}\right)>\mathrm{L}_{1}(\mathrm{R}=\mathrm{H})>\mathrm{L}_{3}(\mathrm{R}=\mathrm{p}-$ $\left.\mathrm{NO}_{2}\right)>\mathrm{L}_{2}(\mathrm{R}=\mathrm{p}-\mathrm{Cl})$

This is in agreement with decreasing electron releasing character of the substituent in the same direction which results in a decrease in the basicity of the azomethine nitrogen of the ligand

Table. 3. Apparent formation constant values $\left(\mathrm{K}_{\mathrm{f}}\right)$ of the different $\mathrm{Cu}(\mathrm{II})$ and $\mathrm{Pd}(\mathrm{II})$ complexes with 2-(Arylmethyleneacetyl)benzimidazole derivatives.

\begin{tabular}{|c|c|c|c|}
\hline Complex & Molar Ratio & Continuous Variation & Mean \\
\hline $\mathrm{Cu}-\mathrm{L}_{1}$ & $5.25 \times 10^{10}$ & $9.045 \times 10^{10}$ & $7.14 \times 10^{10}$ \\
\hline $\mathrm{Cu}-\mathrm{L}_{2}$ & $4.45 \times 10^{10}$ & $7.25 \times 10^{10}$ & $5.85 \times 10^{10}$ \\
\hline $\mathrm{Cu}-\mathrm{L}_{3}$ & $4.92 \times 10^{10}$ & $8.75 \times 10^{10}$ & $6.83 \times 10^{10}$ \\
\hline $\mathrm{Cu}-\mathrm{L}_{4}$ & $5.7 \times 10^{10}$ & $9.46 \times 10^{10}$ & $7.58 \times 10^{10}$ \\
\hline $\mathrm{Pd}-\mathrm{L}_{1}$ & $4.23 \times 10^{10}$ & $7.09 \times 10^{10}$ & $5.66 \times 10^{10}$ \\
\hline $\mathrm{Pd}-\mathrm{L}_{2}$ & $4.09 \times 10^{10}$ & $6.36 \times 10^{10}$ & $5.22 \times 10^{10}$ \\
\hline $\mathrm{Pd}-\mathrm{L}_{3}$ & $4.19 \times 10^{10}$ & $6.61 \times 10^{10}$ & $5.44 \times 10^{10}$ \\
\hline $\mathrm{Pd}-\mathrm{L}_{4}$ & $4.29 \times 10^{10}$ & $7.11 \times 10^{10}$ & $5.70 \times 10^{10}$ \\
\hline
\end{tabular}

and consequently the tendency toward complex formation is expected to decrease.

Based on the evidence discussed above and various physico-chemical studies, the following structures (Fig. 9) can be proposed about the nature of these complexes.

\section{REFERENCES}

1- Ansari, K. F., Lal, C., J. Chem. Sci. 2009, 121 (6), 1017.

2- Alper, S., Temiz-Arpaci, O., Aki-Sener, E., Yalcin, I., Il Farmaco, 2003, 00, 1.

3- Gata, L., Perna, F., Figura, N., Ricci, C., Holton, J., D'Anna, L., Miglioli, M., Vaira, D., J. Antimicrob. Chemother. 2003, 51, 439.

4- Kucukbay, H., Durmaz, R., Orhan, E., Gunal, S., Il Farmaco, 2003, 58, 431.

5- Kazimierczuk, Z., Upcroft, J. A., Upcroft, P., Gorska, A., Starosciak, B., Laudy, A., Acta Biochim. Polon. 2002, 49 (I), 185.
6- Garuti, L., Roberti, M., Cermelli, C., Bioorg. Medicinal Chem. Letter. 1999, 9, 2525.

7. Akbay, A., Oren, I., Temiz-Arpaci, O., Aki-Sener, E., Yalcin, I., Arzneim.- Forcsh./Drug Res. 2003, 53, 266.

8. Casse, C., Giannoni, f., Nguyen, V. T., Dubois, M. F., Bensaude, O., J. Biol. Chem. 1999, 274, 16097.

9- Preston, P. N., Chem. Rev. 1974, 74, 279.

10- Drolet, D. P., Manufa, D. M., Less, A., J. Inorg. Chim. Acta, 1988,146, 173.

11- Verweij, P. D., Dugue, T., Diessen, W. L., Reedijk, J., Rowatt, B., Sherrington, D. C., Reactive Polym. 1991, 14, 213.

12- Gosh, S. P., J. Indian Chem. Soc. 1951, 28, 710.

13- Gosh, S. P. and Gosh, H. M., J. Indian Chem. Soc. 1956, 33, 894 .

14- Goodgame, G. and Cotton, F. A., J. Am. Chem. Soc. 1962, 84, 1543.

15- Goodgame, D. M. L., Goodgame, M., Inorg. Chem. 1965, 4, 139. 
16- Reedijik, J. J., Inorg. Nucl. Chem. 1973, 35, 239.

17- Gumus, F., Algul, O., Eren, G., Eroglu, H., Diril, N., Gur, S., Ozkul, A., E. J. Med. Chem. 2003, 303.

18- Podunavac-Kuzmanović, S. O., Leovac, V. M., PerišićJanjić, N. U., Rogan, J., Balaž, J., J. Serb. Chem. Soc. 1999, 64, 381.

19- Podunavac-Kuzmanović, S. O., Ćetković, G. S, Leovac, Markov, S. L., N. U., Rogan, J. J., Acta Periodica Technologica, 2001, 32, 145.

20- Podunavac-Kuzmanović, S. O., Leovac, V. M., Ćetković, G. S., Markov, S. L., Acta Periodica Technologica, 2002, 33, 151.

21 Podunavac-Kuzmanović, S. O., Lj. S. Vojinović., Acta Periodica Technologica, 2003, 34, 119.

22 - Gayathri, V., Shashikala, N., Nanje Gowda, N. M., Reddy, G.K.N., Ind. J. Chem. 1993, 32A, 38.

23- Podunavac-Kuzmanović, S. O.; Cvetković D. M.; Vojinović, L. S.; APTEFF 2004, 35, 1-280.

24- Hozien, Z. A., J. Chem. Tech. Biotechnol. 1993, 57, 335.

25- Geary, W. J., Coord. Chem. Rev., 1971, 7, 81.

26- Nakamoto, K. Infrared and Raman Spectra of Inorganic and Coordination compounds. 4th edn, J. Wiley and Sons, New York, Chichester, Bribane, Toronto, Singa- pore 1990.

27- Hill, D. G., Rosenberg, A. F., J. Chem. Phys. 1954, 22 , 148.

28- Hill D. G., Rosenberg, A. F., J. Chem. Phys. 1956, 24 , 1219.

29- Kobayashi, M., Fujita, J., J. Chem. Phys. 1955, 23, 1354.

30- Ibrahim, M. M., Ramadan, A. M., mersal, G. A. M., Elshazly, S., J. Mol. Struct. 2011, 998, 1.

31- Ptaszyński, B. and Zwolińska, A. Polish J of Environmental Studies. 2001, 10 (4), 257.

32-M. Abdelbaset, M. Abd-Elmottaleb, Al-Azhar Bull. SCi. 2010, 21 (1) 119.

33- Yoe, J. H., Jones, A. L., Ind . Eng. Chem. Analyst. Edn. 1944, 16, 111.

34- Job, P., Ann .Chem. 1928, 9, 113.

35- Inczedy, J., "Analytical Application of Complex Equilibria", 2nd ed.; Jhon Wiley \& Sons.Inc.: Budapest, 1976.

36- Erk, N., Anal. Lett. 2003, 36, 1183

37- Grinberg, A. A.,Yatsimirsk, K. B., Bull. Acad. Sci. USSR. Div. Chem. Sci. 1952, 239.

38- Irving, H., Williams, R. J. P., J. Chem. Soc. 1953, 3192. 


$$
\text { الملخص العربى }
$$

تحضير وتوصيف ودراسات بيولوجيه على متراكبات أيونات النحاس الثنائى والبلاديوم الثنائى مع مشتقات -2 أريل

$$
\begin{aligned}
& \text { مثيلين اسيتيل بنزاميدازول. } \\
& \text { محمد عبدالباسط معروف }
\end{aligned}
$$

$$
\text { قسم الكيمياء - كلية العلوم - جامعة الأزهر ( فرع أسيوط) }
$$

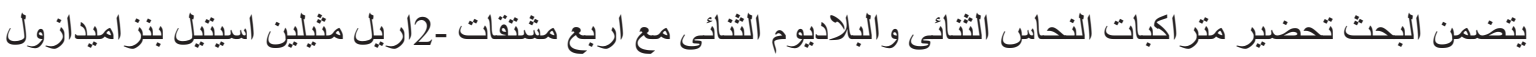

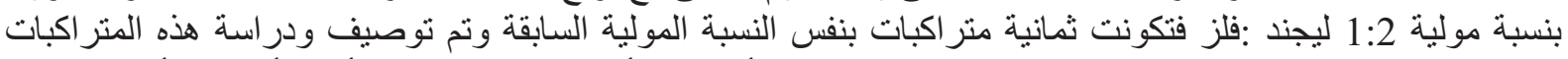

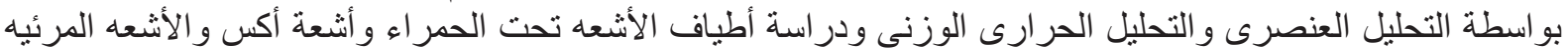

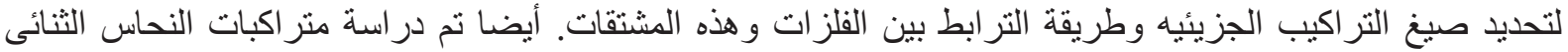

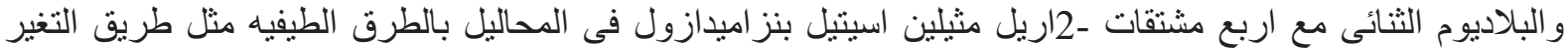

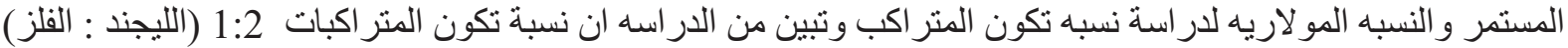

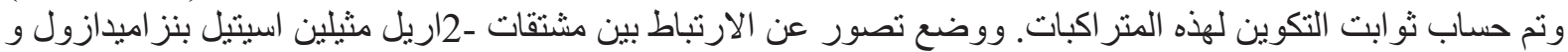

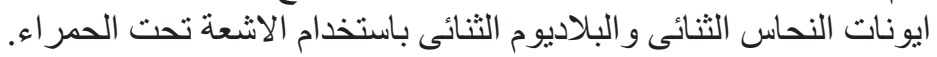

